\title{
MIDWIVES' COMPLIANCE TO THE STANDARD OPERATING PROCEDURE ON THE EARLY IDENTIFICATION OF PREECLAMPSIA
}

\author{
Kepatuhan Bidan terhadap Pelaksanaan Standar Prosedur Operasional \\ Deteksi Dini Preeclampsia
}

*Dian Islami

East Java Provice Health Office, Indonesia

*Correspondence: pocutdian64@gmail.com

\begin{abstract}
Background: The main cause of maternal mortality in East Java was pregnancy hypertension (Preeclampsia/eclampsia). The percentages of pregnant women treated with early identification of preeclampsia care according to Standard Operating Procedure (SOP) in primary healthcare centers of Surabaya was still low (26\%).

Aim: This study aimed to analyze the factors that influence midwives' compliance towards the SOP implementation of early identification of preeclampsia in primary healthcare centers of Surabaya.

Methods: The study was an observational analytic research with cross sectional. The samples chose midwives at 20 primary healthcare centers as the informants. The independent variables are individual factors, organizational factors, and psychological factors of the midwives. The dependent variable was midwives' compliance towards the implementation of SOP for early identification of preeclampsia.

Results: The results of this study show $35 \%$ of primary healthcare centers have not implemented the SOP of early identification of Preeclampsia in pregnant women. The results also showed that the majority of primary healthcare centers in Surabaya had midwives aged 31 to 40 years (50\%), graduated from a Diploma 3 education $(95 \%)$, contracted status (85\%) and still worked less than six years $(60 \%)$.

Conclusion: This research highlighted the midwives' compliance which was determined not only by individual internal factors, but also organizational behavior. Preparing early identification of preeclampsia mechanisms, facility, and equipment proposal is important to do with the implementation of supportive system, quality control team, reward as well as punishment system.
\end{abstract}

Keywords: Compliance, Early identification, Midwives, Preeclampsia, SOP.

\section{ABSTRAK}

Latar Belakang: Penyebab utama kematian ibu di Jawa Timur adalah hipertensi dalam kehamilan (Preeclampsia/eklamsia). Ibu hamil yang mendapatkan pelayanan deteksi dini Preeclampsia sesuai Standar Prosedur Operasional (SPO) di Puskesmas Kota Surabaya masih rendah (26\%).

Tujuan: Penelitian ini bertujuan untuk menganalisis faktor yang mempengaruhi kepatuhan bidan terhadap pelaksanaan SPO deteksi dini Preeclampsia di Puskesmas Kota Surabaya.

Metode: Penelitian ini adalah penelitian analitik observasional dengan rancang bangun cross sectional dan Puskesmas sebagai unit analisis penelitian. Sampel penelitian adalah 20 Puskesmas dengan seluruh bidan di Puskesmas sebagai informan. Variabel independen penelitian yaitu faktor individu, faktor organisasi dan faktor psikologis petugas. Variabel dependen penelitian yaitu kepatuhan pelaksanaan SPO deteksi dini Preeclampsia. Hasil: Hasil penelitian menunjukkan 35\% puskesmas yang belum menjalankan SPO deteksi dini Preeclampsia pada ibu hamil sesuai standar yang berlaku. Hasil penelitian juga menunjukkan bahwa mayoritas pusat kesehatan masyarakat di Surabaya memiliki bidan berusia 31 hingga 40 tahun (50\%), lulus dari pendidikan Diploma 3 (95\%), status kontrak (85\%) dan masih bekerja kurang dari enam tahun (60\%).

Kesimpulan: Penelitian ini menggarisbawahi bahwa kepatuhan bidan tidak hanya ditentukan oleh faktor internal individu, tapi juga perilaku organisasi. Persiapan mekanisme deteksi awal Preeclampsia, fasilitas, dan pengajuan alat penting untuk dilakukan dengan diikuti pelaksanaan sistem yang mendukung, pengkontrol kualitas, dan sistem hadiah dan hukuman.

Kata Kunci: Kepatuhan, Bidan, Deteksi dini, Preeclampsia, SPO.

\section{INTRODUCTION}

Maternal Mortality Rate (MMR) in East Java in 2014 was 93.52 per 100,000 live births, and this figure met the MDGs target in 2015. However, the number of maternal mortality in East Java and other five provinces contributed $50 \%$ of maternal mortality in Indonesia and was at the 3rd highest rate after West Java and Central Java Provinces. East Java Province is encouraged to reduce the number of 
maternal mortality with various breakthrough efforts (East Java Province Health Office, 2014)

The city of Surabaya as the capital city of East Java is one of the contributors to the case of Preeclampsia in pregnant women. According to the East Java Province Health Office Report (2011), Surabaya City ranked $4^{\text {th }}$ with 508 preeclampsia cases (1.24\%). In 2012, it rose to the second place with 767 preeclampsia cases $(1.78 \%)$. Surabaya in 2013 was ranked $2^{\text {nd }}$ with 1.051 preeclampsia cases $(2.27 \%)$. These data indicate that the increase of preeclampsia cases can be one of the main problems of maternal health in Surabaya which need to be addressed immediately. Complete data recording in Surabaya from 2011-2013 has continuously decreased.

The influence of the level of officers' compliance to record and run the Standard Operating Procedure (SOP) on the amount of maternal mortality, and any factors that influence such compliance need to be examined (East Java Province Health Office, 2015). Task Force for Reducing Child and Maternal Mortality Rate or Penurunan Angka Kematian Ibu dan Bayi (Penakib) was formed as an effort to reduce the preeclampsia cases in East Java Province. Penakib forum is a forum that addresses issues that cause maternal and infant mortality. Members of Penakib forum consist of cross-program, cross-sectoral, professional organizations, and educational institutions. From the forum discussion, it was found that Surabaya was pointed to be a model in handling the incidence of maternal and infant mortality and forming cadres which was strengthened by the Mayor of Surabaya Decree No. 188.45 / 338.436.1.2 / 2012.

The cadres of Penakib in Surabaya compiled a Practical Handbook for Handling Preeclampsia and Postpartum Bleeding. The primary health care center of Mulyorejo was designated as a trial model for the implementation of the practical guidebook for handling preeclampsia and postpartum bleeding as outlined in the SOP of early identification of preeclampsia in 2011. Based on the results of the trial, the Head of the Surabaya District Health Office issued a circular letter about the implementation of early identification of preeclampsia throughout Surabaya in April 2014.

Preliminary research was carried out in other primary healthcare centers to find out the SOP of early identification of preeclampsia after the circular letter issued by the Head of Surabaya District Health Office. Observations on 100 maternal and child health handbooks show $26 \%$ of pregnant women underwent early identification of preeclampsia according to the SOP, 26 pregnant women were examined for Roll-Over Test (ROT) and Mean Arterial Pressure (MAP), 74 pregnant women performed body mass index measurement, $66 \%$ of them were detected by early identification of high risk of pregnancy with maternal and child health handbooks. There are $74 \%$ of early identification of preeclampsia checks that are not carried out according to the SOP even though it has become a mandatory provision. This study aims to analyze the factors that influence the compliance to early identification of preeclampsia based on the SOP in Surabaya City health center.

\section{METHOD}

This type of research was analyticobservational with a cross-sectional design. The unit analyzed in this study was Surabaya primary healthcare centers with the informants of all midwives who were selected as the research sample. The population of this study was all primary healthcare centers in Surabaya with twenty primary healthcare centers as the sample. The study was conducted from January to April 2016.

The variables in this study consisted of independent variables namely individual factors (age, education level, employment status, and length of work), organizational factors (managerial function of the heads of primary healthcare centers, availability of documents for early identification Preeclampsia detection, writing of examination results on maternal and child health handbooks, remuneration, rewards and punishment, and supervision) and psychological factors of the officer (perception of work and self-motivation) as well as the dependent variable that includes compliance to early identification of preeclampsia based on the Standard Operating Procedure (SOP).

Primary data were obtained through interviews and observations. The interview was conducted with an interview sheet. Interviews were conducted to obtain information about individual factors (age, level of education, employment status, and length of work), organizational factors (managerial function of the Head of primary health care center, availability of documents of early identification of preeclampsia based on the SOP, writing of examination results on the maternal and child health handbooks, remuneration, reward and punching, and supervision) and psychological factors of the officers (perception of work and selfmotivation).

Observations were made to assess compliance to early identification of preeclampsia based on the SOP. Researchers took the maternal and child health handbooks in each primary health care center to assess the completeness of recording. The results of the examination from secondary data were obtained from the Surabaya District Health Office in the form of the number of midwives at primary healthcare centers, SOP for early identification of high risk pregnant women, and completeness of antenatal care records (maternal and child health handbooks) as well as data of preeclampsia case ranking by district/city from the East Java Province Health Office. To enrich the results of the study, researchers conducted an FGD (Focus Group Discussion) with the Head of puskesmas, midwife coordinators, and midwives of the primary healthcare centers who were selected as the research sample.

Influence test on the independent variables consisting of individual factors of officers (age, education level, employment status, and length of work), organizational factors (managerial function of Head of community health center, availability of preeclampsia SOP documents, writing of examination results on the maternal and child health handbooks, remuneration, rewards and punishment, and supervision), and the psycho-physical factors of 
the officers (perception of work and self-motivation) on the dependent variable that is adherence to the implementation of early identification of preeclampsia based on the Standard Operating Procedure (SOP) by using multiple linear regression test. Determining the strategic issues of this research, in addition to using the results of a significant influence test, researchers also used Pareto analysis. The frequent distribution of weak/poor assessment results with a percentage of more than $20 \%$ will be raised as a strategic issue.

\section{RESULTS AND DISCUSSION}

Midwives' compliance towards the implementation of early identification of preeclampsia based on the Standard Operating Procedure is divided into two categories, namely low and high. The description of compliance with the implementation of early identification of preeclampsia based on the Standard Operating Procedure can be seen in Table 1.

Table 1. Compliance of Early Identification of Preeclampsia in Primary Healthcare Centers of Surabaya based on SOP in 2016.

\begin{tabular}{|c|c|c|}
\hline Compliance & $\mathbf{n}$ & $\%$ \\
\hline Low & 7 & 35.0 \\
\hline High & 13 & 65.0 \\
\hline Total & 20 & 100 \\
\hline
\end{tabular}

Table 1 shows that $65 \%$ of primary healthcare centers in Surabaya have obeyed early identification of preeclampsia according to the Standard Operating Procedure. All midwives in Surabaya health centers are required to apply early identification of preeclampsia to prevent maternal death. The higher level of adherence of midwives at the primary healthcare centers to carry out early identification of preeclampsia according to the Standard Operating Procedure can reduce maternal mortality due to preeclampsia.

Compliance is obedience to receiving instructions, correction, provision, and protection from leaders (Oak, 1992). Matindas (2002) states that disciplined behavior is loyalty and obedience. The compliance to early identification of preeclampsia based on the Standard Operating Procedure includes the way midwives carry out examinations of Body Mass Index (BMI), MAP, and ROT on pregnant women in accordance with the established Standard Operating Procedure and writing examination results on the maternal and child health handbooks.

Donelly, Gibson, and Ivancefich (1995) state that adherence is one form of behavior that affects someone's performance. The compliance of midwives in carrying out early identification of preeclampsia based on the Standard Operating Procedure will provide an overview of the examination results that will determine the type of service for pregnant women. Proper implementation of Standard Operating Procedure on preeclampsia detection can make pregnant higher-risk women early detected. Health workers and family members can immediately try to handle and prevent complications during pregnancy, childbirth, and childbirth.

Preeclampsia is the most common cause of maternal death in East Java. In 2011, Surabaya became the fourth highest city/regency where preeclampsia cases occurred in East Java. The rating rose to the second highest ranking in 2012 with a total of 767 cases. Thus, the implementation of early identification of preeclampsia by health workers, especially midwives, can help reduce the incidence of eclampsia cases in Surabaya. Furthermore, it is expected to reduce MMR in East Java, especially in Surabaya City.

Individual factors of officers consist of demographic characteristics including age, education level, employment status, and length of work. The results showed that the majority of primary healthcare centers in Surabaya had midwives aged 31 to 40 years (50\%), graduated from a Diploma 3 education (95\%), contracted status (85\%) and still worked less than six years $(60 \%)$. Demographic characteristics are also important things known by the leader or someone to motivate and improve their performance (Gibson, 1997).

Organizational factors are important factors that can influence the behavior of employees or workers (midwives). Organizational factors consist of managerial factors and socialization factors. The organization's managerial factors consist of managerial functions of the heads of primary health care center, document availability of Standard Operating Procedure for early identification of Preeclampsia, writing of examination results on the maternal and child health handbooks, remuneration, reward and punishment, and supervision. The socialization factor consisted of information on the implementation of Standard Operating Procedure, orientation, and training in the form of On the Job Training (OJT).

The results showed that the majority of primary healthcare centers in Surabaya had managerial functions. The heads of the primary healthcare centers were ranked as good $(80 \%)$ which was supported by the completeness of maternal and child health handbooks writing in the medium category $(85 \%)$. The remuneration given to midwives was sufficient $(90 \%)$. The supervision was done once every six months $(65 \%)$. The heads also gave good implementation information (100\%), and there are orientation steps for early identification of preeclampsia (100\%). Reward and punishments are not applied at work (95\%). However, training in early identification of preeclampsia is not optimal $(55 \%)$, and there is no Standard Operating Procedure document for early identification of preeclampsia (55\%).

The psychological factors of the officers consisted of perceptions of the work and selfmotivation of the midwife of Surabaya health centers. The majority of primary healthcare centers in Surabaya have self-motivated midwives who are currently implementing Standard Operating Procedure for early identification of preeclampsia $(65 \%)$ and good job perception $(90 \%)$. This means that the midwives feel primary healthcare centers feel cannot fully meet the need to carry out early identification of preeclampsia. The influence test of 
independent variables on the compliance to the Standard Operating Procedure for early identification of Preeclampsia was carried out using multiple linear regression test with $\alpha$ of 0.05 .

Table 2. The Effect of Independent Variables on SOP of Early Identification of Preeclampsia.

\begin{tabular}{|c|c|c|}
\hline Variable & B & $p$-value \\
\hline \multicolumn{3}{|l|}{$\begin{array}{l}\text { Individual } \\
\text { Factor of } \\
\text { Officers }\end{array}$} \\
\hline Age & -0.284 & 0.129 \\
\hline $\begin{array}{l}\text { Education } \\
\text { Level }\end{array}$ & -0.790 & $0.003^{*}$ \\
\hline $\begin{array}{l}\text { Employee } \\
\text { Status }\end{array}$ & -0.080 & 0.695 \\
\hline Work Period & 0.097 & 0.641 \\
\hline \multicolumn{3}{|l|}{$\begin{array}{l}\text { Organizational } \\
\text { Factors }\end{array}$} \\
\hline $\begin{array}{l}\text { Head's } \\
\text { managerial } \\
\text { function }\end{array}$ & -0.632 & $0.032^{*}$ \\
\hline $\begin{array}{l}\text { Document } \\
\text { availability of } \\
\text { Standard } \\
\text { Operational } \\
\text { Procedure }\end{array}$ & 0.165 & 0.369 \\
\hline $\begin{array}{l}\text { Writing of } \\
\text { Maternal and } \\
\text { child health } \\
\text { handbooks }\end{array}$ & 0.205 & 0.341 \\
\hline Remuneration & -0.203 & 0.276 \\
\hline $\begin{array}{l}\text { Reward and } \\
\text { Punishment }\end{array}$ & 0.057 & 0.772 \\
\hline Supervision & -0.066 & 0.734 \\
\hline \multicolumn{3}{|l|}{$\begin{array}{l}\text { Officers' } \\
\text { Psychological } \\
\text { Factors }\end{array}$} \\
\hline $\begin{array}{l}\text { Work } \\
\text { Perception }\end{array}$ & 0.031 & 0.903 \\
\hline $\begin{array}{l}\text { Self- } \\
\text { Motivation }\end{array}$ & 0.872 & $0.003^{*}$ \\
\hline
\end{tabular}

Table 2 shows that the individual factors of officers, organizational factors and officers' psychological factors influence the compliance to the Standard Operating Procedure for early identification of preeclampsia. Sub-variables of individual factors of the officers who influence the compliance to the Standard Operating Procedure for early identification of preeclampsia is the level of education. Subvariables of organizational factors that influence the compliance is the managerial function of the Heads. Meanwhile, sub-variable of officers' psychological factor is self-motivation.

The sub-variable of education level has a $p$ value (significance) of 0.003 or meaning smaller than $\alpha(0.05)$, so null hypothesis is rejected. In other words, the level of education has a significant effect on the compliance to the Standard Operating Procedure for early identification of preeclampsia. The $B$ value obtained is -0.79 . The negative value (-) shows the opposite relationship between these two variables. The higher the level of education is, the lower the compliance is.
Sub-variable of Heads' managerial function has a p-value (significance) of 0.032 or which means smaller than $\alpha(0.05)$, so null hypothesis $(\mathrm{Ho})$ is rejected. In other words, the sub-variables of perception of the need for managerial functions have a significant effect on the compliance to early identification of preeclampsia based on the Standard Operating Procedure. The value of $b$ obtained is 0.632 . The negative value $(-)$ shows the opposite relationship between these two variables. The higher the results of the assessment of managerial functions are, the lower the compliance to the Standard Operating Procedure is.

Sub-variables of self-motivation have a $p$ value (significance) of 0.003 or meaning smaller than $\alpha(0.05)$, so null hypothesis $(\mathrm{Ho})$ is rejected. In other words, the self-motivation sub-variables have a significant effect on the compliance of the early identification of Preeclampsia SOP. The B value obtained is 0.872 . A positive value $(+)$ shows a linear relationship between these two variables. The higher self-motivation is, the higher the level of adherence to the early identification of Preeclampsia based on the Standard Operating Procedure.

Gibson (1997) states that individual variables are categorized into sub-variables of ability and skill, background and demographics. Ability and skill variables include physical, mental (EQ), and intelligence (IQ). Ability and skill are the main factors that influence behavior and individuals. Gibson (1997) adds that demographic sub-variables have an indirect effect on individual behavior and performance.

The results showed that the age of midwives in the Surabaya health centers had no significant effect on the compliance. The results showed that the majority of midwives in the primary healthcare centers of Surabaya were 31-40 years old. The age range is a mature age in carrying out the duties and responsibilities related to the compliance of the SOP compared to the age of the diploma fresh graduates, which is approximately 23 years. Age affects a person's mindset. Mindset influences a person's behavior and mindset becomes one of the indicators in decision making that refers to each experience, with increasing age, the individual will be more responsible in receiving instruction and in carrying out a procedure. Increasing age, more and more experience, consideration, strong work ethic, and commitment to quality are seen (Robbins, 2008).

The results of this study are in line with the research of Kurniawati (2014) which states that age does not affect the compliance to the Standard Operating Procedure. The findings are not in line with Anugrahini's (2010) study which states that there was a significant relationship between age and compliance. The influence of age on compliance to the Standard Operating Procedure is determined by the target of each study so that there are some findings who are in line with the results of this study, but some are not.

The demographic character possessed by individual factors that influence compliance (age, gender, educational background, years of service and marital status) can affect someone's compliance (Gibson, 1997). Many individual factors or demographic characteristics beyond age can affect 
the implementation of Standard Operating Procedure for early identification of preeclampsia.

Sisdiknas (2009) states that types and levels of tertiary education are divided into academic education, which means that postgraduate and higher education programs are directed more for mastering scientific disciplines, such as undergraduate, master and doctoral degrees. The results of the study showed that education level affected the compliance to early identification of Preeclampsia based on the Standard Operating Procedure, but both had negative relationships. The higher the level of education is, the lower the adherence to the implementation of Standard Operating Procedure is.

Midwives with Diploma 4/Bachelor Degree/Master Degree tend to not pay attention to the small things related to medical techniques. Midwives with Diploma 3 have skills of medical technical management. Handling preeclampsia cases with early identification requires excellent technical management, but they are directed more to managerial matters rather than midwifery management. Therefore, the influence of education level is negatively related to midwife's compliance in implementing early identification of Preeclampsia based on the Standard Operating Procedure.

The results of this study are in line with Saragih and Rumpea (2010) which state that the higher education level is, the lower the compliance of the Standard Operating Procedure is. Also, the results of this study are also in accordance with research conducted by Mada, Susilo, and Nekada (2013) which show that the longer a person's work experience is, the better the knowledge is possessed to implement the Standard Operating Procedure. This study is different from Hikmah (2008) who conducted a similar study and said there was no relationship between the education level and the perception of nurses in implementing patient safety guidelines.

The results also showed that there was one primary health care center with the majority of midwives with a Diploma 4 / Bachelor Degree / Master Degree, but most of midwives' work duration in the primary healthcare centers was only one to six years. These primary healthcare centers had low compliance. The results of the study are in accordance with Notoatmojo (2007) who said that the level of education also influences someone's knowledge. A high education level does not guarantee good knowledge. Work experience related to working time and age also influences someone's knowledge. Work experience possessed by individuals shows types of work and opportunities for individuals to work better. The more work experience a person has and the more skilled individual can do in his work, the more perfect the way of thinking and attitude is in acting to achieve the goals that have been formulated (Puspaningsih, 2004).

Employment status is defined as the state or position of a person or body (organization) in the relationship with their surroundings while employment is something related to employees (Sholihah, 2004). Employment status is the condition or position of employees in their work environment. Law No. 13 of 2003 about labor is legally known as 2 (two) types of workers, namely contract workers and permanent workers or workers with indefinite work period (Presiden Republik Indonesia, 2003). Each institution has a different definition of permanent employees and temporary employees. There are two types of employment status owned by midwives, namely contracts and civil servants in this study (Ministry of Health of Republic Indonesia, 2013).

The results showed that employment status did not affect the compliance to the Standard Operating Procedure. Contract employees should be more obedient in carrying out the management of Early identification of preeclampsia because it is related to the work agreement, so the work agreement is not terminated. Status as a contract employee should become motivation for the midwives in carrying out their work.

The results of this study are in line with research conducted by Nuryati and Kusumasari (2015) who found that employment status does not have a significant influence on performance. The results of this study are contrary to Met and Ibrahim (2014) which show that there is a significant relationship between employment status and motivation and performance. Performance, in this case, is observed through adherence to the implementation of early identification of Preeclampsia based on the Standard Operating Procedure.

Work period is the average time of works in a health center from the first time as an employee or officer in the health center to now. Seniority and productivity in work are positively related. The longer a person works, the more skilled and more experienced they are in completing their work (Anugrahini, 2010).

The results showed that work period did not affect the implementation of Standard Operating Procedure for early identification of preeclampsia. The longer a midwife works, the more experience they have at work. The work experience will make midwives better to respond to everything related to their work, such as decision making, problemsolving, and so on.

The results of this study are in line with the results of Hikmah's research (2008) which states that there is no relationship between the period of work and the perception of health workers on the importance of Standard Operating Procedure implementation. The results of this study are contrary to the results of Yusran's (2008) study which suggests that there is a positive correlation between the period of work and compliance to Standard Operating Procedure.

An organization is a formal union system with two or more people who work together to achieve goals (Hasibuan, 2012). An organization is a social unity that is consciously coordinated with two or more people, who function on a relatively continuous basis to achieve a goal or set of goals that have been set together (Robbins and Judge, 2007). The managerial function of the heads of the primary healthcare centers includes the perception of the midwife about the heads' managerial function in giving instructions to the midwives to obey the Standard Operating Procedure. The ways to achieve the organization's goals can be done through motivation, 
communication and monitoring. This perception is measured based on the midwife's assessment towards the head's leadership role in the primary healthcare centers to carry out managerial functions. The leadership roles being assessed include: (1) giving clear instructions regarding the implementation of Standard Operating Procedure for early identification of preeclampsia (2) motivating midwives (3) communicating related problems found in the implementation of early identification of preeclampsia according to standards (4) conducting periodic monitoring and evaluation.

Gillies (1994) defines leadership based on the verb, which is to lead, such as to guide, to show a particular direction, to direct, to walk ahead, to be the first, to open the game, and to tend to specific results. Leadership is an art or process to influence others so that they are willing and with their abilities and enthusiastically work to achieve the goals set by the organization (Weihrich and Koontz, 1993).

The results showed that the perception about the heads' managerial function in the primary healthcare centers had a significant effect on the compliance of implementing the Standard Operating Procedure. The relationship between these variables is negative. It means that the better the perception about the heads' the managerial function is, the lower the adherence level is to the implementation of Standard Operating Procedure. Based on the FGDs results, some of the heads of primary healthcare centers did not work as general practitioners, but several heads were dentists. The ability of each head is different in terms of understanding about the importance of Standard Operating Procedure for early identification of preeclampsia.

In fact, it shows that the heads' managerial function has generally been carried out well, but the heads still often encounter obstacles about technical mastery of examinations that must be carried out by midwives. The primary competency that must be possessed by the heads of primary healthcare centers is to carry out managerial functions well, not technical mastery. Therefore, the implementation of early identification of preeclampsia is often not noticed because of the limited understanding of the heads especially that of heads that are not doctors. This can decrease the compliance of implementing the Standard Operating Procedure for early identification of preeclampsia (Islami, 2016).

The results of this study are in line with the research of Dolphina (2012) which states that the implementation of managerial leadership activities does not necessarily provide a positive impact or good morning workers. If the higher implementation of managerial leadership activities is carried out, it can affect the company's performance from time to time. The leadership activities that tend to encourage employees is likely to give an employee's job satisfaction, but not necessarily able to bring a positive influence on personality formation, such as sincerity in working and achieving the work goals. One of the work objectives that can be represented in this study is the implementation of early identification of preeclampsia based on the Standard Operating Procedure. The findings are not in line with the results of Anugrahini's research (2010) which states that accurate perceptions of leadership carried out by leaders have a positive effect on compliance with the implementation of Standard Operating Procedure.

The document availability of Standard Operating Procedure is measured based on whether or not the document is stored in an accessible place. The documents of the Standard Operating Procedure can be transformed into a more practical and concise form and posted at the midwife's checkpoint so that it can be read clearly. The results showed that the document availability did not affect the implementation of Standard Operating Procedure for early identification of preeclampsia in Surabaya. The results showed the majority of primary healthcare centers did not have Standard Operating Procedure for early identification of preeclampsia.

Observations showed that the early identification guided most of Surabaya health centers through the circular letter from Surabaya District Health Office. Each primary health care center had not made an early identification preeclampsia based on the Standard Operating Procedure and posted it well in the examination room. This made the researchers consider that there was no Standard Operating Procedure. The management of the primary healthcare centers and Surabaya District Health Office should take initiatives to make practical examination guidelines for early identification of preeclampsia and post them in the room where the midwife examines the patient. This result is in line with Haryanti's (1991) research which states that the existence of procedural documents does not affect the midwife's compliance towards antenatal care standards.

Midwifery documentation is a proof of recording and reporting useful activities for partners, midwives, and health teams in providing health services based on effective communication and midwives' responsibilities. Midwifery documentation is also defined as a complete and accurate record of circumstances in midwifery activities. Maternal and child health handbooks is a patient's medical record that must be appropriately filled according to the examination results, and its confidentiality is maintained (Sudarti, 2010).

The results showed that there was no influence on writing of medical record on the maternal and child health handbooks towards the compliance to implement the Standard Operating Procedure for early identification of preeclampsia. The unavailability of the BMI, MAP and MOP columns on the maternal and child health handbooks to write the detection results proved not to affect the implementation of early identification of preeclampsia based on the Standard Operating Procedure. The results showed that $85 \%$ of midwives consider the columns for BMI, MAP, and MOP on the maternal and child health handbooks to remind midwives of measuring and filling track. The availability of columns is necessary since it influences midwives' compliance in accomplishing the Standard Operating Procedure for early identification of preeclampsia.

The results of the study are in line with Minarni's (2011) research which states that there is no significant influence on the availability of facilities towards the implementation of Standard Operating Procedure. The results of this study are not in line 
with the research conducted by Sariningdyah (2001) which states that there is an influence on the availability of facilities towards the compliance to the Standard Operating Procedure for antenatal care.

The FGD results explicate midwives often find it difficult to write down the results of early identification of preeclampsia because there is no column referred on maternal and child health handbooks. Midwives tend to be reluctant to carry out early identification of preeclampsia because they feel confused to write the medical record. Therefore, stakeholders, such as District Health Office, should revise the current maternal and child health handbooks format (Haryanti, 1991).

According to Oxford Dictionaries, remuneration means "remunerated" or pay (someone) for accomplished service or work. Remuneration in KBBI means giving gifts (rewards for services), rewards. The remuneration system for each worker is a part of the bureaucratic reform that has been established by the government. The results showed that remuneration did not affect the implementation of Standard Operating Procedure for early identification of preeclampsia. There were $90 \%$ of midwives in the primary healthcare centers who thought that the remuneration provided was sufficient. Adequacy of remuneration makes midwives motivated to do good work on the early identification of preeclampsia. Uninfluential remuneration on compliance can be caused by other factors. The informants consisted of contract midwives and civil servants. The remuneration system is only applied to civil servants' status.

This result is in line with the research conducted by Olfah (2012) which states that satisfaction of remuneration does not affect performance. In contrast to Palagia, Brasit, and Amar (2010) which states that there is an influence on the remuneration given towards officer's performance at the tax office. The Ministry of Finance has initiated some reformation in the bureaucracy. That is to change the remuneration system from just personal and occupational considerations to grade-based remuneration. Bureaucratic reformation needs to be carried out gradually to accelerate the ranks for civil servants, initiated by the Ministry of Finance, by changing the remuneration system where the income earned by employees other than salary is based on class, and incentives as current work performance should be given. These incentives are considered from education and knowledge, experience, scope of work, complexity of the work type, and nature of the problems that must be solved, supervision received, supervision responsibility /supervision on others, decision impact, consequences of errors, working relationships that must be carried out, and working environment conditions. Regulations about employee's performance in the Ministry of Health are explained in the Presidential Regulation of the Republic of Indonesia Number 110 Year 2015 (Presiden Republik Indonesia, 2015).

A reward can be rewards, wages, and gifts (Shadily and Echols, 2004). Chaplin (2004) states that reward can be an incentive, a situation, or an oral statement that can trigger satisfaction or increase the likelihood of action. A reward is generally used to regulate employee's working hours in an organization. It means that rewards will make an employee work without the control of the leader, but according to their responsibilities.

Punishment is given due to a violation of applied regulations. Unlike positive rewards, punishment tends to be negative. Nevertheless, if punishment is applied appropriately and wisely, it will be a trigger for employees or officers to increase their productivity. In general, punishment is divided into two types, namely preventive punishment and repressive punishment (Indrakusuma, 2000). Preventive punishment is given in order to prevent violations. Repressive punishment is carried out because of a violation.

The results showed that reward and punishment did not affect the compliance to early identification of preeclampsia based on the Standard Operating Procedure. The uninfluential reward and punishment on the implementation of early identification of preeclampsia can also be caused by the fact that most of midwives considered that reward and punishment has never been applied to their performance. Ninety-five percent of midwives consider that reward and punishment has never been implemented.

Reward and punishment require midwives to be motivated in doing their work and responsibilities, especially the implementation of early identification of preeclampsia based on the Standard Operating Procedure. Midwives feel satisfied with an excellent job because they will be given incentives, praise, and career advancement. Midwives will also feel embarrassed if they get punished in the form of reprimand. Thus, reward and punishment is significant to be implemented.

The results of the study are in line with the research of Anugrahini (2010) which states that there is no meaningful relationship between rewards (reward) and the officers' compliance to the Standard Operating Procedure. In contrast to the studies of Nelson and Plost (2007) who found that nurses who received rewards tend to be more compliant to the implementation of Standard Operating Procedure in the ICU (Intensive Care Unit).

Azwar (1996) states that supervision is the activity of conducting direct and periodic observations carried out by superiors on the work performed by subordinates who are immediately given direct instructions or assistance as a problem solution. Supervision is a part of the process of controlling and supervising functions (Muninjaya, 1999). Swanburg (2000) views supervision aspect as accessible resources needed in order to complete a task or set of activities for decision-making and employee's performance evaluation. Supervision at the Surabaya health centers was carried out by the Surabaya District Health Office and the East Java Province Health Office.

The results showed that the supervision conducted by the Surabaya District Health Office did not affect the compliance to early identification of preeclampsia based on the Standard Operating Procedure. Surabaya District Health Office often supervises the performance of primary healthcare centers, but they do not focus on the implementation of eEarly identification of preeclampsia. The supervision carried out by Surabaya District Health 
Office generally still focus on Mother and Child Health $(\mathrm{MCH})$ and Family Planning Program carried out by the primary healthcare centers. Therefore, although most of midwives in each primary health care center has a good response about the supervision carried out by the Surabaya District Health Office, it has not yet had a significant influence on the compliance of early identification of preeclampsia.

The supervision conducted by the Surabaya District Health Office may not influence the compliance to early identification of preeclampsia based on the Standard Operating Procedure due to subjective assessment done by the midwives. Relationships between supervisors and supervisee in clinical supervision are significant. Sloan and Watson (2002) in their research stated that policies set by the supervisor would influence supervisee's perceptions. A good supervisor's policy can influence the assessment and perception of the supervisees to choose the supervisor. The compliance to the implementation of early identification of preeclampsia based on the Standard Operating Procedure is measured objectively by researchers based on predetermined examination standards. The results of this study are not in accordance with Mardianti (2015) which states that supervision is the most dominant variable associated with midwife's compliance. This finding is contrary to the research conducted by Basuki (2012) which stated that there was no meaningful relationship between supervision and compliance.

Psychological variables are complicated and difficult to measure because individual's attitudes towards the organizational work differ from one another in terms of age, ethnicity, cultural background, and skills. This factor tends to be influenced by social level, family, previous work experience, and demographic characteristics. Psychological factors in this study are based on Gibson's (1997) perception about work and selfmotivation.

Perception is a cognitive process used by individuals to interpret and understand the world around them (Gibson et al., 1997). According to Winardi (2004), perception is a cognitive process, where a person gives meaning to the environment. The perception variable was measured based on the midwife's assessment on the importance of procedures for early identification of preeclampsia. These procedures include the Standard Operating Procedure, maternal examination flow according to the Standard Operating Procedure, BMI examination procedures for pregnant women, MAP examination procedures in each pregnant woman, and ROT examination procedures on every pregnant woman.

The results showed that the perception about work did not affect the implementation of Standard Operating Procedure for early identification of preeclampsia. The majority of midwives have a good perception about work. Midwives can perceive that the high number of preeclampsia cases in Surabaya can increase maternal and infant mortality. Maternal mortality is one of indicators for the Human Development Index (HDI) of Surabaya City. This means that midwives understand that the implementation of early identification of preeclampsia may reduce maternal mortality and affect the HDI of Surabaya.

The results of the study are not in line with the research of Natasia, Loekqijana, and Kurniawati (2014) which states that perceptions influence the adherence of Standard Operating Procedure. Gibson (1997) states that there are psychological factors that can affect someone's compliance, such as attitudes, perceptions, personality, learning, and motivation. There are psychological factors beyond the perception that can also affect someone's compliance to implement the Standard Operating Procedure.

The term "motivation" comes from the Latin "movere" which means "to move" or move. The basic word for motivation is "motive" which means encouragement and reason for an individual to do something. Work motivation is defined as a process in which individual's work behavior is energized, directed, and maintained at work and organizational life (Armstrong, 2004). The results showed that selfmotivation had a significant positive effect on the implementation of early identification of preeclampsia based on the Standard Operating Procedure. Midwives' self-motivation in doing work determines the employees' performance. Fulfillment of midwife's rights (salary that meets their needs and is received on time, saving and assurance fulfillment, equipment fulfillment and work utensil with rewards, friendly leadership, good relations with superiors, a comfortable work atmosphere, good relationships with colleagues at work) can increase midwives' motivation to work and accomplish early identification of preeclampsia based on the Standard Operating Procedure.

This result is in line with research conducted by Natasia, Loekqijana, and Kurniawati (2014) which states that there is a significant relationship between motivation and level of compliance. In general, motivation factors have a strong relationship with performance. Thus, it can be predicted that if midwife's self-motivation increases, their compliance will also improve their performance (Badi'ah, 2009). The results of this study are different from the research conducted by Mulyono et al. (2013), which states that there is no significant influence between work motivation and performance. It was found that the implementation of Standard Operating Procedure can be caused by factors that influence motivation including individual characteristics and job characteristics (Mulyono et al., 2013).

The influence of midwives' self-motivation on early identification of preeclampsia based on the Standard Operating Procedure should be a special concern for managerial section in the primary healthcare centers because improving midwives' self-motivation to be more obedient is important to implement the Standard Operating Procedure for early identification of preeclampsia. The relationship between motivation and employee's performance is where someone's motivation will encourage individual's desire to perform certain activities in order to achieve a goal (Herisman, 2006) so that the incidence of maternal mortality due to Preeclampsia can be prevented.

The individual's work motivation can come from within the individual itself so-called internal 
motivation, or due to factors originating from outside or so-called external motivation) (Armstrong, 2004). Individual motivation depends on the strength of the motives. A motive is a state within an individual or what is called an inner state that encourages, activates, moves, directs, and channels individual behavior towards the process of achieving goals (Koontz, 1990). Mangkunegara (2015) states that internal or intrinsic motivation can be generated through proper wages, job security, working conditions, company procedure status.

Efforts to improve midwives' self-motivation can be done through the implementation of a reward system. Most informants considered that a reward system for midwife's performance had not been implemented so far. Reward is something to make a favorable climate that triggers workers to work more productively and improve work performance. Reward can be in the form of praise, awards, holiday allowances, bonuses, and service stars. Hasibuan and Malayu (2003) state that the right motivation can be delivered directly to employees to meet their needs and satisfaction.

The research conducted by Natasia, Loekqijana, and Kurniawati (2014) stated that factors influencing the compliance of health workers in implementing the Standard Operating Procedure are self-motivation and perception about work. Also, the results of Anugrahini's research (2010) show that there is a significant relationship between age, education level, tenure, leadership, organizational structure, and work design and the compliance of health workers in implementing the Standard Operating Procedure.

\section{CONCLUSION}

There are primary healthcare centers that have not implemented the Standard Operating Procedure for Early identification of preeclampsia for pregnant women. Education level, managerial function of the heads of primary healthcare centers and self-motivation have a significant effect on the compliance to the Standard Operating Procedure for Early identification of preeclampsia.

It is suggested to relevant stakeholders, such as primary healthcare centers, Surabaya District Health Office, East Java Province Health Office. For primary healthcare centers, it is necessary to make instructions related to the preparation of early identification mechanisms, facility and equipment proposal by implementing a supportive system, forming a quality control team, and applying the reward and punishment system for early identification of preeclampsia.

Moreover, Surabaya District Health Office should be able to meet the equipment needs of primary healthcare centers in carrying out early identification of preeclampsia by facilitating the supporting system implemented by primary healthcare centers and supervising as well as strengthening the implementation and evaluation of early identification of preeclampsia. The East Java Province Health Office needs to implement and determine early identification of preeclampsia based on the Standard Operating Procedure as an instrument to prevent the occurrence of preeclampsia cases in all East Java Province Health Office.

\section{CONFLICT OF INTEREST}

The authors declare that they have no conflict of interests.

\section{REFERENCES}

Anugrahini, C. (2010) Hubungan Faktor Individu dan Organisasi dengan Kepatuhan Perawat dalam Menerapkan Pedoman Patient Safety di RSAB Harapan Kita. Thesis. Universitas Indonesia.

Azwar, A. (1996) Menjaga Mutu Pelayanan Kesehatan. Jakarta: Sinar Harapan.

Basuki, D. (2012) Hubungan Persepsi Perawat Pelaksana tentang Supervisi Pimpinan Ruang dengan Pelaksanaan Standar Operasional Prosedur Pemberian Obat Parental Itravena di Rumah Sakit Daerah Sidoarjo. Thesis. Universitas Indonesia.

Chaplin, J. . (2006) Kamus Lengkap Psikologi Terjemahan Kartini Kartono. Jakarta: Rajagrafindo Persada.

Dolphina, E. (2012) 'Pengaruh Motivasi, Kepemimpinan dan Budaya Kerja terhadap Kepuasan Kerja Karyawan serta Dampaknya pada Kinerja Perusahaan', in Seminar Nasional Teknologi Informasi \& Komunikasi Terapan. Semarang.

East Java Province Health Office (2011) Profil Kesehatan Provinsi Jawa Timur Tahun 2012. Surabaya.

East Java Province Health Office (2015) Profil Kesehatan Provinsi Jawa Timur Tahun 2014. Surabaya.

Donelly, J. H., Gibson, J. L. and Ivancefich, J. M. (1995) Fundamentals of Management. Chicago: Irwin.

Gibson, E. J. (1997) 'An ecological psychologist's prolegomena for perceptual development: A functional approach.', in Evolving explanations of development: Ecological approaches to organism-environment systems. C. Dent-Re. Washington, DC: American Psychological Association, pp. 2345.

Gillies (1994) Nursing management: System approach. 3rd edn. Philadelpia: W. B. Saunders Co.

Haryanti (1991) Analisis Faktor-faktor yang Mempengaruhi Kepatuhan Bidan pada Standar Pelayanan Antenatal dengan Berpedoman Buku KIA di Kodia Salatiga. Universitas Gajah Mada.

Hasibuan (2012) Manajemen Sumber Daya Manusia. Jakarta: Bumi Aksara.

Hasibuan and Malayu, S. . (2003) Manajemen Dasar, Pengertian, dan Masalah. Jakarta: PT. Toko Gunung Agung.

Herisman (2006) Hubungan Persepsi dan Motivas Kerja Pegawai Administrasi dalam rangka meningkatkan Kinerja pada Pengadilan Negeri Bengkulu. Thesis. Universitas Terbuka. 
Hikmah, S. (2008) Persepsi Staf Mengenai 'Patient Safety' di Instalasi Rawat Darurat (IRD) RSUP Fatmawati. Skripsi. Universitas Indonesia.

Indrakusuma, A. (2000) Pengantar Ilmu Pendidikan. Surabaya: Usaha Nasional.

Koontz, H., Donnell, C.O. and Weihrich, H. (1993) Manajemen. 1st edn. Jakarta: Erlangga.

Kurniawati, T. (2014) Buku Ajar Kependudukan dan Pelayanan KB. Jakarta: Egc.

Mada, M.D., Susilo, C.B., and Nekada, C. D. (2013) 'Hubungan Pengetahuan Perawat Tentang Infeksi Nosokomial dengan Penerapan Prinsip Steril pada Pemasangan Infus di Rs Kristen Lende Moripa, Sumba Barat. Universitas Respati Yogyakarta', Journal Medika Respati, 8(1).

Mangkunegara, A. P. (2015) Manajemen Sumber Daya Manusia. Bandung: PT. Remaja Rosda karya.

Mardianti (2015) 'Faktor-faktor yang Berhubungan dengan Kepatuhan Bidan Dalam Pencegahan Infeksi pada Pertolongan Persalinan di Tingkat Puskesmas Kabupaten Karawang Tahun 2013', Jurnal Kebidanan Indonesia, 6(2).

Matindas, R. (2002) Manajemen Sumber Daya Manusia, Lewat Konsep Ambisi Kenyataan dan Usaha. Jakarta: Pustaka Utama Grafiti.

Minarni (2011) Faktor-faktor yang Mempengaruhi Kepatuhan Dokter Gigi dalam Menerapkan Standar Prosedur Operasional Pencabutan pada Gigi pada Sarana Pelayanan Kesehatan Gigi di Kota Bukit Tinggi dan Kabupaten Agam. Universitas Gajah Mada.

Ministry of Health of Republic Indonesia (2013) Pedoman Penyelenggaraan Puskesmas Mampu PONED. Jakarta: Ministry of Health of Republic Indonesia.

Ministry of Health of Republic Indonesia (2014) Laporan Akuntabilitas Kinerja Direktorat Bina Kesehatan Ibu. Jakarta.

Mulyono, M. H., Hamzah, A. and Abdullah, A. Z. (2013) 'Faktor Yang Berpengaruh Terhadap Kinerja Perawat Di Rumah Sakit Tingkat III 16.06.01 Ambon', Jurnal AKK, 2(1), pp. 1826.

Natasia, N., Loekqijana, A. and Kurniawati, J. (2014) 'Faktor yang Mempengaruhi Kepatuhan Pelaksanaan SOP Asuhan Keperawatan di ICU-ICCU RSUD Gambiran Kota Kediri', Jurnal Kedokteran Brawijaya, 28(1).

Nuryati, M. and Kusumasari, B. (2015) Pengaruh Status Kepegawaian, Insentif, dan Lingkungan Kerja terhadap Kinerja Pegawai di Program Studi S2 IImu Kesehatan Masyarakat Fakultas Kedokteran UGM Yogyakarta. Thesis. Universitas Gajah Mada.

Oak (1992) How to Develop Obedience: Character Booklet 2. Illinois: Institute in Basic Life Principles.

Olfah, S. T. (2012) Pengaruh Kepuasan pada Remunerasi, serta Motivasi Kerja terhadap Kinerja Pegawai yang Dimoderasi oleh Masa Kerja (Kasus di Lingkungan Direktorat Jenderal Anggaran). Thesis. Universitas Terbuka.
Palagia, M., Brasit, N. and Amar, M. . (2010) 'Remunerasi, Motivasi, dan Kepuasan Kerja terhadap Kinerja Pegawai pada Kantor Pajak', Jurnal Analisis, 1(1).

Presiden Republik Indonesia (2003) UndangUndang Republik Indonesia No. 13 Tahun 2003 tentang Ketenagakerjaan. Indonesia.

Presiden Republik Indonesia (2015) Tunjangan Kinerja di Lingkungan Kementerian Kesehatan. Indonesia.

Puspaningsih, A. (2004) 'Faktor-faktor yang berpengaruh terhadap Kepuasan Kerja dan Kinerja Manajer Perusahaan Manufaktur', $J A A l, 8(1)$.

Robbins, Stephen P. (2008) Organizational Behaviour, 10th edn. Jakarta: Salemba Empat.

Robbins, S. P. and Judge, T. . (2007) Organizational behavior. 12th edn. Upper Saddle River, NJ: Pearson Prentice Hall.

Saragih and Rumapea (2012) 'Hubungan Karakteristik Perawat dengan Tingkat Kepatuhan Perawat Melakukan Cuci Tangan di RS Columbia Asia Medan'. Medan.

Sariningdyah (2001) Faktor yang Berhubungan dengan Kepatuhan Bidan Puskesmas terhadap Standar Pelayanan Antenatal. Thesis. Universitas Gajah Mada.

Shadily, H. and Echols, John M. (2004) Kamus Inggris Indonesia. Jakarta: PT. Gramedia Utama.

Sholihah (2004) Hubungan antara Status Kepegawaian dengan Kinerja Guru (Studi Kasus pada Guru MI se- Kecamatan Susukan). Thesis. Sekolah Tinggi Agama Islam Negeri Salatiga.

Sloan and Watson (2002) 'Clinical Supervison Models For Nursing: Structure, Research, and Limitation', Pubmed.gov, 17(4).

Sudarti (2010) Asuhan Kebidanan Neonatus, Bayi, dan Anak Balita. Yogyakarta: Nuha Medika.

Swanburg, R. (2000) Kepemimpinan dan Manajemen Keperawatan. Jakarta: Egc.

Weihrich., Heinz. and Koontz., Harold (1993) Management: A Global Perseption. 10th edn. Singapore: McGraw Hill Inc.

Winardi (2004) Manajemen Perilaku Organisasi. Jakarta: Penerbit Prenada Media.

Yusran (2008) Analisis Tingkat Pengetahuan Perawatan terhadap Kepatuhan dalam Membuang Sampah Medis di RSUD Abdoel Moelok. Thesis. Universitas Malahayati. 